\title{
Vývoj globálneho diskurzu vzdelávacej politiky a nové sociálne funkcie predškolského vzdelávania
}

\author{
Ondrej Kaščák \\ Trnavská univerzita $\vee$ Trnave, Pedagogická fakulta \\ a Univerzita Karlova, Filozofická fakulta
}

\begin{abstract}
Abstrakt: Štúdia sa zaoberá spôsobmi globálnej správy vzdelávania a súčasnými mechanizmami nadnárodného ovplyvňovania vzdelávacích systémov a to najmä s dôrazom na vzdelávanie a starostlivost' v ranom detstve (VSRD). Cez diachrónnu analýzu diskurzu klúčových dokumentov OECD a EU d'alej objasňuje novú politickú konceptualizáciu VSRD a aj sektora raného vzdelávania ako takého. Táto nová konceptualizácia, založená na prospektívnom a ekonomizujúcom vnímaní formovania $v$ ranom detstve, je $v$ špecifických národných kontextoch uplatňovaná prostredníctvom rôznorodých reformných mechanizmov a procesov. Tieto mechanizmy sú opísané na príklade aktuálneho vývoja na Slovensku a v Nemecku. Štúdia pre sektor VSRD potvrdzuje platnost' tzv. konvergenčnej hypotézy a to aj napriek diverzite tradícií VSRD v Európe.
\end{abstract}

Klúčové slová: vzdelávanie a starostlivost' v ranom detstve (VSRD), OECD, EÚ, sociálno-investičná paradigma, Slovensko, Nemecko, konvergenčná hypotéza

\section{Development of Global Discourse of Educational Policy and New Social Functions of Early Childhood Education}

Abstract: The study analyses the nature of global education governance and the mechanisms of transnational influencing of national education systems today, with an emphasis on early childhood education. Through a discursive analysis of key OECD and EU documents, it clarifies the new conceptualization of the early childhood education and early childhood education sector as such. The conceptualization, based on a prospective and economizing view, is promoted through various reform mechanisms within particular national contexts. The study gives examples of reform movements in Slovakia and Germany. The study confirms the validity of the so-called convergence hypothesis for early childhood education, despite the diversity of early childhood education traditions in Europe.

Keywords: early childhood education, discourse, OECD, EU, social investment paradigm, Slovakia, Germany, convergence hypothesis

Miera investícií Európskej únie do predškolského vzdelávania a produkcia relevantnej legislatívy $v$ ostatných pätnástich rokoch naznačuje vysokú prioritizáciu sektora predškolského vzdelávania. Desiatky analytických správ OECD taktiež naznačujú, že v oblasti globálnych školských politík získava predškolské vzdelávanie úplne novú pozíciu a dôležitost'. A aj tí významní reprezentanti OECD, ktorí sa intenzívne venovali najmä sekundárnemu vzdelávaniu a pripravenosti 15-ročných na nové požiadavky trhu práce, sa zrazu zameriavajú na najmenších a dokonca o predškolskom vzdelávaní pravidelne publikujú. Za všetkých možno spomenút' „otca“ medzinárodného 
10 testovania PISA A. Schleichera. S vysokou prioritizáciou však ide ruka v ruke predstavovanie predškolského vzdelávania $v$ novom svetle a $v$ novom kontexte. Úlohou tejto štúdie je tento nový kontext opísat', ozrejmit' jeho špecifiká a nuansy. Taktiež je úlohou tejto štúdie ukázat', ako sa tento kontext cez pôsobenie nadnárodných organizácií prenáša do národných vzdelávacích politík.

Štúdiu možno lokalizovat' v oblasti komparatívnej pedagogiky. Budeme v nej postupovat' tak, že najprv ozrejmíme podoby globálnej správy vzdelávania a mechanizmy nadnárodného ovplyvňovania národných vzdelávacích systémov v súčasnosti. Následne budeme analyzovat' globálny diskurz vplyvných nadnárodných organizácií a zoskupení, ktorý sa vzt’ahuje k predškolskému vzdelávaniu. Metódou práce bude diachrónna komparácia vývoja nadnárodného diskurzu vzdelávacej politiky na základe autoritatívnych dokumentov, čiže analýza a porovnávanie v časovej kontinuite. V prípade dokumentov OECD to bude obdobie od roku 2001 do roku 2017. V prípade dokumentov EÚ obdobie od roku 1996 do roku 2018. Budeme postupovat' analýzou diskurzov vybraných relevantných dokumentov o predškolskom vzdelávaní a ranej starostlivosti v kontinuu ich vývoja.

Základ analýzy diskurzu tvorí snaha vysvetlit' ideologický kontext, v rámci ktorého diskurzy vznikajú a získavajú dominanciu (Turunen \& Rafferty, 2013). Predmetom našej analýzy budú dominantné diskurzy. Tie privilegujú špecifický spôsob myslenia a vylučujú iné perspektívy. Vyextrahujeme z nich typické diskurzívne jednotky a formácie, ktoré vyjadrujú podstatu nového ponímania predškolského vzdelávania a sektora, ktorý predškolské vzdelávanie poskytuje. V analýze diskurzov zohl'adníme viaceré úrovne dominantného diskurzu - text, hlas, naráciu (Humes, 2000). Na úrovni textu ide o to, čo bolo povedané, aké centrálne koncepty boli prezentované, aké opakujúce sa metafory boli používané. Na úrovni hlasu ide o mocenské rozloženie vzt'ahov za diskurzom - kto hovorí a je oprávnený hovorit', koho perspektíva sa zdôrazňuje (napr. pedagógov, ekonómov, zamestnávatel'ov). No a hlasy kontrolujúce text konštruujú naráciu (Humes, 2000, s. 48), príbeh, ktorý legitimizuje výpoved' (napr. príbeh o úspešných žiakoch, rastúcej ekonomike, prosperujúcej spoločnosti a pod.).

Diskurzívne formácie v strategických dokumentoch o vzdelávaní a starostlivosti $\checkmark$ ranom detstve (VSRD) môžu mat' rôzne podoby. V priebehu 20. storočia nachádzame viac alebo menej systematické familializačné diskurzy, diskurzy vychádzajúce z práv žien, holisticko psychologizujúce diskurzy, pedocentrické diskurzy, diskurzy vychádzajúce $z$ detských práv, či socializačné a inštitucionalizačné diskurzy. Úlohou tejto štúdie je opísat' prevládajúce diskurzívne formácie vo vybraných dokumentoch nadnárodných organizácií. Nie je jej úlohou glorifikovat' či hanit’ niektorú diskurzívnu formáciu, ale skôr ozrejmit’ zdroje, stopy a penetrácie prevládajúcej formácie, či formácií. Pri analýze sa však nevyhneme kontrastovaniu ako prostriedku porovnávania a práve z kontrastovania môže vzniknút' dojem kritiky či legitimizácie. Používame pritom kontrastovanie diskurzov napr. tak, ako to robí Casalini (2014). Kontrastovanie používame na to, aby sa ukázala neprítomnost' nejakého alternatívneho diskurzu alebo diskurzov, pričom ale ciel'om tejto štúdie nie je tento diskurz/y d'alej 
analyzovat'. Predstavuje/ú tak len komparatívny bod, ktorý ukazuje dominantný diskurz v jeho nesamozrejmosti.

Okrem novej a komplexnej konceptualizácie predškolského vzdelávania v dominantných diskurzoch nadnárodných organizácií poukážeme na odporúčania týchto organizácií smerujúce k národným vzdelávacím politikám, aby sa táto konceptualizácia uplatnila. Taktiež poukážeme na nové globálne nástroje presadzovania a vyhodnocovania tejto novej konceptualizácie. Následne na dvoch národných príkladoch (Slovenska a Nemecka) ukážeme, ako sa uvedená konceptualizácia a jej implementačné mechanizmy presadili $v$ ich národných politikách predškolského vzdelávania.

\section{Postupy nadnárodného a medzinárodného ovplyvňovania}

Globálna redefinícia predškolského vzdelávania je možná len vtedy, ak existuje mechanizmus, ktorý umožňuje transformáciu národných vzdelávacích systémov. Najčastejšie má takýto mechanizmus podobu tzv. výpožičky politík (policy borrowing and lending). Ide o proces, ktorý bol dokladovaný už v 19. storočí, ked’ bol napr. pruský model predškolského vzdelávania v podobe „kindergarten“ implementovaný v USA (Malatinská, 2014). Najčastejšie ide o proces medzinárodného ovplyvňovania prostredníctvom tzv. najlepších praxí (best practices) a môže mat' viaceré podoby. Ak istá krajina sama vyvíja úsilie, hladá nové vhodné modely a aktívne ich na seba implementuje, tak sa zdôrazňuje aspekt „požičania si“ efektívnej politky (policy borrowing), zatial'čo „zapožičanie“ či „poskytnutie“ politík (policy lending) skôr zdôrazňuje externé vplyvy na národné systémy (napr. vplyvy nadnárodných organizácií) (Portnoi, 2016).

Intenzita externého vplyvu, ale aj motívy výpožičky môžu byt' rôzne. Preto Ochs a Phillips (2004, s. 9) stanovili akési kontinuum vzdelávacieho transferu, kde uviedli pät' základných existujúcich podôb takéhoto transferu politík: 1) vynútený transfer (totalitné, autoritatívne politiky); 2) požadovaný pod nátlakom (porazené či kolonizované krajiny); 3) vyjednaný pod nátlakom (požadovaný bilaterálnymi alebo multilaterálnymi dohodami); 4) ciel'avedomo vypožičaný (zámerné kopírovanie politík/ praxí sledovaných niekde inde); 5) zavedený na základe ovplyvnenia (všeobecné ovplyvnenie vzdelávacími ideami a metódami). V rámci tejto štúdie bude transfer globálnej koncepcie a modelu predškolského vzdelávania analyzovaný najmä v kontexte krajín, ktoré sú členmi OECD a EÚ, krajín globálneho severu. V prípade slovenskej vzdelávacej politiky síce historicky možno hovorit’ aj o transferoch typu 1) a 2), no po páde komunizmu sú relevantné najmä transfery typov 3), 4) a 5), pričom po období uchádzania sa o členstvo v OECD a predvstupových rokovaní s EÚ, kedy dominoval typ 3), dnes popri typu 3) rastie aj význam typov 4) a 5).

V inej štúdii Phillips a Ochs (2003) na príkladoch opisujú rôzne varianty štyroch fáz výpožičiek vzdelávacích politík. 1) medzinárodnej prít’ažlivosti; 2) rozhodnutia k výpožičke; 3 ) implementácie politík; 4) internalizácie/udomácnenia politík. Ukazujú, že v súčasnosti je dominantným motívom k výpožičkám negatívna národná 
12 skúsenost' (napr. nespokojnost' rodičov, zlé výsledky v medzinárodných testovaniach atd’.), ktorá vedie k rozhodnutiam národných vlád k výpožičke. Vol'ba prenášaného modelu však často býva podnecovaná čisto teoreticky, alebo ovplyvnená klamlivou osobnou skúsenost'ou. Taktiež môže byt' poháňaná snahou rýchlo vyriešit' istý akútny problém. Tieto motivácie však väčšinou vedú k neefektívnosti výpožičiek v národnom vzdelávacom systéme.

\title{
2 Globálna vzdelávacia politika
}

\begin{abstract}
Vlády stále viac zohl'adňujú medzinárodné porovnania vzdelávacích príležitostí a výsledkov, ked' tvoria politiky pre zlepšovanie sociálnych a ekonomických vyhliadok indivíduí, ked' uplatňujú stimuly pre vyššiu efektívnost' v školstve a pomáhajú mobilizovat' zdroje aby uspokojili zvyšujúce sa požiadavky. Direktoriát OECD pre vzdelávanie a zručnosti prispieva k týmto snahám prostredníctvom tvorby a analýzy kvantitatívnych, medzinárodne porovnatel'ných indikátorov, ktoré každoročne publikuje v materiály Education at a Glance. Spolu s hodnotiacimi správami o národných politikách krajín OECD môžu byt' tieto indikátory nápomocné vládam pri budovaní efektívnejších a spravodlivejších vzdelávacích systémov. (OECD, 2018b, s. 3)
\end{abstract}

Tento úvodný odstavec z materiálu Education at a Glance uvádzame v plnom rozsahu, pretože na malom priestore vyjadruje základný rámec tvorby globálnej vzdelávacej politiky. Ide v ňom o vyjadrenie misie silnej nadnárodnej organizácie v oblasti školskej politiky. V tomto vyjadrení sa však nezrkadlia len ambície tejto organizácie „pomáhat'“ vládam a riadit’ vzdelávacie transfery na medzinárodnej úrovni. Zároveň vyjadruje očakávaný spôsob správy vzdelávania zo strany vlád - na základe medzinárodných porovnaní a kvantitatívnych indikátorov. Taktiež vyjadruje konečné ciele resp. zmysel správy vzdelávania - zlepšenie sociálnych a ekonomických vyhliadok indivíduí, stimulovat' efektívnost', mobilizovat' zdroje. Cez takúto mobilizáciu majú vlády reagovat' na zvyšujúce sa požiadavky, takže vo výroku je správa vzdelávania chápaná reaktívne voči d’alším externým faktorom. Nedá sa nevnímat', že v tomto prípade ide o vel'mi redukovanú, ekonomizujúcu predstavu o tvorbe vzdelávacích politík a o správe vzdelávania. Dnes sa však všeobecne prijíma fakt, že ide o najrozšírenejšiu a globalizovanú predstavu.

Na úrovni všeobecnej vzdelávacej politiky je táto globalizovaná predstava zhmotnená vo viacerých „globálnych trendoch v školstve“ (Portnoi, 2016, s. 87). Prvým z nich je marketizácia vzdelávania, pričom dochádza $\mathrm{k}$ hodnotovému posunu - rovnost' a sociálnu mobilitu ako cielové kategórie vzdelávania strieda všade zdôrazňovaná sociálna efektivita. Vzdelávanie ako verejné blaho strieda koncept vzdelávania ako obchodovatel'nej komodity, ako niečoho uplatnitel'ného najmä (či výhradne) na trhu práce. Druhým trendom je korporativizácia, teda uplatnenie korporátneho étosu v školstve. Zároveň ide o snahy budovat' partnerstvá s firemným sektorom, či pri správe vzdelávania vytvárat' verejno-privátne partnerstvá. Tretím trendom je decentralizácia, privatizácia vzdelávania a logika volby/výberu. Nárast sút'aživosti (oproti kooperácii) medzi školami, nárast podielu súkromných škôl, zvyšujúce sa 
náklady na verejné vzdelávanie, či dokonca zavádzanie rôznych poplatkov vo verejnom vzdelávaní, sú vyjadrením tohto trendu. Štvrtým trendom je zavádzanie prvkov akontability a štandardizovaného testovania do školských systémov. Súvisí so snahou disponovat' kvantitatívnymi dátami, ktoré ovplyvnia rozhodovacie procesy tak, ako o tom hovorí prvý odstavec správy Education at a Glance. Zároveň tieto prvky posilňujú kontrolné mechanizmy $v$ systéme. Tento ciel' je podporovaný piatym trendom a tým je rastúci význam IKT v správe vzdelávania, či už pri evidencii, vykazovaní, či štandardizovanom testovaní.

Portnoi $(2016$, s. 113) uvádza, že dnes platí „konvergenčná hypotéza vo vzdelávani“", t. j. že globálne sa jednotlivé národné vzdelávacie systémy a ich prvky stále viac a viac podobajú, približujú sebe navzájom a snažia sa implementovat' uvedené globálne trendy. Ukazuje sa teda, že vzdelávací transfer je pomerne jednosmerný, smeruje od krajín, ktoré sú nadnárodnými organizáciami uvádzané ako vzorové, k d’alším krajinám. Voči tomuto pohybu však silnejú kritické hlasy poukazujúce na devastáciu rôznych tradičných prvkov vzdelávacích systémov $v$ transformujúcich sa krajinách, týkajúcich sa najmä transmisie kultúrnych noriem, religiozity, či pôvodných vzdelávacích modelov.

\section{Globálni hráči v predškolskom vzdelávaní}

Konvergenčné trajektórie vo väzbe na uvedené globálne trendy v školstve možno sledovat' aj v sektore predškolského vzdelávania, ktorý tradične nebýval súčast’ou intenzívneho komparatívneho výskumu $v$ pedagogike a to najmä preto, lebo v medzinárodnom meradle nie je výhradne pokrytý rezortom školstva resp. sa tak intenzívne nespájal s ideou vzdelávania (silná prítomnost' idey starostlivosti). Globálnym prijatím konceptu celoživotného vzdelávania však všetci významní globálni hráči začali tomuto sektoru venovat' zvýšenú pozornost', systematicky zhruba od začiatku nového milénia. Najvýznamnejšími globálnymi hráčmi sa v tejto oblasti stali Svetová banka, OECD, UNESCO a EÚ. Nejde pritom o izolovaných hráčov. Vo svojich materiáloch často na seba odkazujú a zároveň autorské či posudzovatel'ské tímy často obsahujú zástupcov, ktorí pracujú či pracovali v projektoch inej z týchto organizácií.

Neznamená to však, že diskurz týchto organizácií je úplne homogénny. Mahon (2016) uvádza, že najviac redukovanú, ekonomizujúcu predstavu predškolského vzdelávania má Svetová banka. Naopak, UNESCO je podla nej otvorené rôznym názorovým prúdom (a diskurzom) o význame a cieloch predškolského vzdelávania a tieto prúdy v diskurzoch organizácie aj koexistujú. ${ }^{1}$ OECD stojí niekde medzi uve-

Postavenie UNESCO však bude nevyhnutné v súčasnosti prehodnotit'. Aktuálne iniciatívy totiž naznačujú obrat k tvrdším evidence-based a štandardizačným nástrojom (MELQO - Measurement of Early Learning Quality and Outcomes; LMTF - Learning Metrics Task Force; HECDI - Holistic Early Childhood Development Index), ktoré smerujú proti kontextualizácii a diverzite konceptov detstva a predškolského vzdelávania. 
14 denými pólmi, najmä z dôvodu umiernenejších a nejednoznačných prvých správ o predškolskom vzdelávaní. Vývoj v ostatných 10 rokoch tento diskurz však posúva k ekonomizovanej predstave.

Ak je však ciel'om tohto príspevku poukázat' na meniaci sa koncept predškolského vzdelávania v rozvinutých krajinách, nebudú pre túto analýzu nosné diskurzy Svetovej banky či UNESCO. Tie totižto v sektore predškolského vzdelávania primárne zasahujú ciel'ové krajiny týchto organizácií a to sú najmä rozvojové či transformujúce sa krajiny. Týmto krajinám poskytujú špecifickú asistenciu a prostredníctvom rozvojových projektov aj finančnú pomoc resp. pôžičky. Netreba si však pod tým predstavit' len vzdialený rozvojový svet globálneho juhu, ale napr. aj transformujúce sa postkomunistické krajiny. Napr. Svetová banka momentálne investuje 47 miliónov eur do projektu Inkluzívne vzdelávanie a starostlivost' $v$ ranom detstve $v$ Srbsku. Ako na druhej strane hovorí Mahon (2016), OECD svoju perspektívu smeruje na jadro svojich členských krajín, ktoré tvoria najmä rozvinuté krajiny globálneho severu. Preto pre našu analýzu budú nosné najmä diskurzy OECD a EÚ.

V nami analyzovanom období obe nadnárodné organizácie prechádzajú funkčnou reštrukturalizáciou ovplyvnenou novými trendami verejnej správy, ktoré sú známe ako nový verejný manažment (new public management - NPM) (Klimovský, 2010). Jeho nosnými prvkami sú decentralizácia, individualizácia, privatizácia, marketizácia a úspornost' verejnej správy, presun od monitorovania vstupov na vyhodnocovanie výstupov či tlak na akontabilitu a responzibilitu. V devät'desiatych rokoch 20. storočia zriad'uje OECD direktoriát PUMA (public management), ktorý začal aktívne šírit’ agendu NPM v členských štátoch (Pal, 2012). V prípade Európskej únie presadeniu konceptu NPM napomohla kríza v Európskej komisii v druhej polovici devät'desiatych rokov 20. storočia. Nasledujúca reforma európskych štruktúr navrhovaná Neilom Kinnockom vyústila do širokej aplikácie princípov NPM, čím prišlo k opusteniu francúzskeho modelu správy EK založenom na weberovských princípoch (Quinlivan \& Schön, 2002). Všetky tieto charakteristiky neoliberálnej správy následne zásadne ovplyvnili aj konceptualizáciu správy vzdelávania u oboch organizácií (Tolofari, 2005).

\subsection{OECD}

Pre ozrejmenie vplyvu OECD na členské a aj nečlenské krajiny sa treba pozriet' na organizáciu vzt’ahov s členskými krajinami a spôsob produkcie diskurzu v rámci tejto organizácie. OECD neuplatňuje rozpočtové, penalizačné či sankčné mechanizmy ako je to napr. v prípade Svetovej banky. Členské štáty môžu správy a odporúčania OECD kludne ignorovat'. Napriek tomu sa to nedeje. Spôsob ovplyvňovania má iný charakter. V článku 3 zakladajúcej zmluvy sa uvádza, že členské štáty „sa (a) budú navzájom informovat' a budú poskytovat' Organizácii informácie nevyhnutné pre splnenie jej úloh; (b) na kontinuálnej báze budú spolu konzultovat', realizovat' štúdie a participovat' na dohodnutých projektoch...“ (OECD, 1960). Členské štáty sa zaväzujú poskytovat’ informácie a byt’ v neustálom „konzultačnom“ procese. Mahon (2009, 
s. 186) to označuje ako „mäkké formy regulácie“. Ked’ členské krajiny poskytujú informácie, ktoré následne OECD porovnáva, analyzuje, vytvorí rankingy, označí niektoré národné riešenia a politiky za „najlepšie praxe“ (best practices) a na základe nich dá vo vytvorenej správe špecifické odporúčania, tak sa pre členské štáty automaticky stávajú regulátorom reforiem, ked’že boli v danom informačnom procese zaangažované. OECD tak na základe svojich analýz vytvára a diseminuje odporúčania smerujúce k optimálnym politikám.

Ďalšiu vel'mi významnú regulačnú procedúru tvoria národné správy, ktoré pre jednotlivé oblasti OECD vypracováva a ktoré sú priamo určené vybraným krajinám. Vypracovávajú ich zahraniční experti kontrahovaní OECD konzultujúci s národnými expertmi. Pre oblast' predškolského vzdelávania bol napr. vypracovaný dokument s názvom Quality Matters in Early Childhood Education and Care: Slovak Republic 2012 (Taguma, Litjens, \& Makowiecki, 2012). V tejto edícii autorský tím behom dvoch rokov vypracoval až desat’ národných správ. O regulačných ambíciách týchto správ vypovedá ich štruktúra.

V úvode sa rekapituluje, ktorú z piatich oblastí kvality predškolského vzdelávania stanovených OECD sa rozhodla Slovenská republika rozvíjat' ako prioritnú prostredníctvom národných politík. Ide teda o potvrdenie záväzku, pričom však treba povedat', že uvedených pät' oblastí kvality formulovala OECD v predchádzajúcej globálnej správe o predškolskom vzdelávaní s názvom Starting Strong III (viac vid' nižšie). Následne daná správa analyzuje jednotlivé aspekty zvolenej oblasti a to z porovnávacieho hladiska. Kapitola 2 sa už názvom priamo pýta, aká je pozícia Slovenska v porovnaní s ostatnými krajinami. $V$ tejto kapitole sa používajú mnohé porovnávacie štatistiky, no zároveň sa text štruktúruje do častí s odporúčacími ambíciami. Okrem časti Silné stránky, nachádzame v tejto kapitole čast' Potenciálne oblasti pre reflexiu, čiže oblasti, v ktorých má SR potenciál na zlepšenie. V d'alšej kapitole sa priamo hovorí o výzvach pre vzdelávaciu politiku. Jednak sa formulujú akési spoločné výzvy, neskôr sa sumarizuje úsilie Slovenskej republiky, aby sa napokon navrhli alternatívne stratégie vzdelávacích politík. Pod nimi si treba predstavit' vlastne návrhy OECD na vzdelávacie výpožičky, ked'že sa uvádzajú príklady najlepších praxí z vybraných krajín, prostredníctvom ktorých by sa dali prekonat' uvedené výzvy. Ide o Švédsko, Fínsko, Nórsko a Nový Zéland.

Tieto „mäkké formy regulácie“ by však neboli efektívne, keby neexistovalo akési pozitívne nastavenie národných autorít na zavádzanie nových politík v zmysle uvedených odporúčaní či alternatívnych stratégií. Postoj ministerstva k tomuto dokumentu možno vidiet' hned', ako si na jeho stránkach v sekcii regionálneho školstva klikneme na podsekciu Predprimárne vzdelávanie v materských školách. Daná správa OECD je tu uvedená medzi základnými dokumentmi týkajúcimi sa predškolského vzdelávania v SR. Naviac, kvôli čo najširšej diseminácii sa ministerstvo rozhodlo kompletne túto správu preložit' do slovenského jazyka spolu s materským, omnoho obsiahlejším, viac ako 350-stranovým dokumentom OECD Starting Strong III.

Dokumenty zo série Starting Strong začala OECD produkovat' od roku 2001. Išlo o prvú systematickú iniciatívu, v ktorej sa OECD z porovnávacieho hladiska začala 
16 venovat' predškolskému vzdelávaniu. V tomto období OECD taktiež publikuje sériu národných správ s názvom Babies and Bosses, ktorá sleduje problematiku najrannejšieho detstva a rodinných politík. Vzdelávanie a starostlivost' v ranom detstve v komplexnom ponímaní sa tak stávajú klúčovým predmetom záujmu OECD. V pohlade na predškolské vzdelávanie a v odporúčaniach spojených s politikami v tomto sektore zaznamenala OECD istý vývoj.

Prvá správa Starting Strong (OECD, 2001) sa „snažila prezentovat' kultúrne senzitívnu analýzu služieb vzdelávania a starostlivosti v ranom detstve v rozličných krajinách OECD“ (Campbell-Barr \& Bogatić, 2017, s. 1463). Ako dopĺňa Moss a kol. (2016, s. 344), táto správa bola „citlivá na diverzitu a komplexnost’ systémov a pedagogík“ raného detstva. V koncepcii predškolského vzdelávania zostala nevyhranená a otvorená viacerým modelom. Taktiež rovina odporúčaní je pomerne utlmená v prospech komparatívnych analýz. Konceptuálne sa táto správa zameriava aj na komplexný rozvoj diet'at'a (holisticko psychologický diskurz), nielen na inštitucionalizáciu raného detstva (inštitucionalizačný diskurz).

Situácia sa postupne mení o pät' rokov neskôr, kedy vychádza druhá správa (OECD, 2006). V nej sa nachádzajú nové momenty odporúčacieho charakteru. Jednak je to propagovanie integrovaného prístupu (kap. 2) k vzdelávaniu a starostlivosti v ranom detstve. Odporúča sa vytvárat' systémové modely vzdelávania a starostlivosti pre všetky deti vo veku 0-6 rokov a istá miera centralizácie správy takéhoto sektora v tom zmysle, že na centrálnej úrovni (OECD, 2006, s. 47) má príst’ ku koordinácii politík raného vzdelávania a starostlivosti. Taktiež sa má vykonat' administratívna integrácia tým, že sa stanoví jedno klúčové ministerstvo zodpovedné za správu celého integrovaného sektora. $V$ texte sú priamo uvedené príklady z krajín, ktoré reagovali „na výzvu pre viac systematický prístup“ (s. 48). Predškolské vzdelávanie sa taktiež tematizuje vo viac inštitucionalizovanom svetle. Súvisí s tým aj samostatná kapitola pracujúca so špecifickým pojmom „scholarizácia“ (schoolification) (s. 62) vzdelávania a starostlivosti $v$ ranom detstve. $V$ nej sa tematizujú rôzne aspekty vzt’ahov k primárnemu vzdelávaniu či k školskej pripravenosti. Do správy sa zavádza aj úplne nový moment - odkazy na ekonomické analýzy hovoriacich o návratnosti investícií do predškolského vzdelávania na systémovej úrovni a rodičovských investícií na individuálnej úrovni. Doslovne sa hovorí o najväčšom význame predškolského vzdelávania pri „formovaní humánneho kapitálu“ (s. 37). Ide o prvý významný vstup teórie humánneho kapitálu do nadnárodného diskurzu o predškolskom vzdelávaní (Campbell-Barr \& Nygård, 2014).

Prvok ekonomickej efektivity investícií do raného vzdelávania už nachádzame priamo v prehovore k tretej správe. Zároveň sa význam predškolského vzdelávania redukuje najmä na prínos k vzdelávacím výsledkom:

Stále rastúci súbor dôkazov naznačuje, že deti so solídnymi základmi pre učenie a prosperitu získanými v ranom detstve budú mat’ lepšie výsledky vo svojom neskoršom živote. Tieto dôkazy viedli tvorcov politík k príprave raných intervencií a prehodnoteniu ich rozpočtových vzorcov $v$ oblasti výchovy a vzdelávania tak, aby prinášali protihodnotu za vynaložené prostriedky. (OECD, 2012, s. 3) 
Ako hovorí Moss (2017, s. 17), od tejto správy píše OECD nový príbeh, príbeh kvality a vysokej návratnosti, ktorý tvorí globálne dominantný diskurz. Treba pripomenút', že od tretej správy majú všetky správy Starting Strong nejaký podtitulok. V tomto prípade Súbor nástrojov kvality pre vzdelávanie a starostlivost' v ranom detstve. Súbor nástrojov kvality (A Quality Toolbox) naznačuje, že správa má ambíciu byt’ príručkou efektívnych politík, chce štandardizovat' sektor a inštrumentalizovat' prístup k problematike predškolského vzdelávania. Dos Santos Sousa, Grey a Oxley (2019, s. 43) hovoria o posune ku kvantitatívnemu a na výsledky orientovanému prístupu, ktorý kladie čoraz väčší dôraz na ekonomickú a psychologickú metriku nezávislú od kontextu predškolského vzdelávania.

Tento univerzalizujúci a štandardizačný moment nachádzame v danej správe takmer všade. Nachádzame tu napr. poukaz na potrebu centralizácie a univerzalizácie kurikula na národnej úrovni:

Trendy smerujúce k decentralizácii a diverzifikácii politiky a poskytovania služieb prinášajú do tvorby programov a ich kvality na miestnej úrovni väčšiu rôznorodost'. Spoločný rámec by pomohol zabezpečit' vyrovnanú úroveň kvality v rôznych formách poskytovania VSRD a pre rôzne skupiny detí... (OECD, 2012, s. 71)

Správa dokonca smeruje ku globálnej štandardizácii štruktúry kurikúl, ked' určuje osem kritických oblastí učenia (s. 75-77), ktoré v zásade tvoria odporúčané základné vzdelávacie oblasti jednotného kurikula.

Štvrtá správa (OECD, 2015) má podtitul Monitorovanie kvality vo vzdelávaní a starostlivosti $v$ ranom detstve. Doplňuje koncepciu predchádzajúcej správy o informácie o kontrolných mechanizmoch v predškolskom vzdelávaní, čím ešte viac posilňuje svoj normatívny a univerzalizujúci charakter. Správa odporúča vytváranie koherentných národných monitorovacích systémov založených na národných štandardoch a reguláciách, centrálnom monitorovacom rámci, štandardizovaných monitorovacích nástrojoch (OECD, 2015, s. 205-209). U všetkých týchto mechanizmoch uvádza príklady najlepších praxí z vybraných členských krajín. Výsledky monitorovania majú byt' podla správy podkladom pre reformu vzdelávacích politík. Význam monitoringu je legitimizovaný zvýšenými investíciami do sektora, aby bola neustále garantovaná ich efektívnost' a „akontabilita“ (s. 50). Monitoring majú vykonávat' prevažne verejné inštitúcie z verejných zdrojov. Ako výnimočný príklad v decentralizovanom kontexte uvádza správa príklad Berlína (s. 54), ktorý vytvoril komplexný systém monitorovania kvality v predškolských inštitúciách. Zaujímavé je konštatovanie, že tento systém vznikol ako reakcia na neúspech Nemecka v prvom kole medzinárodného testovania PISA 15-ročných žiakov, pričom sa efektívna kontrola sektora raného vzdelávania začala ponímat' ako nástroj zlepšovania vzdelávacích výsledkov v neskoršom období.

Piata správa (OECD, 2017) pokračuje v línii vnímania raného vzdelávania vo väzbe na školskú úspešnost'. Jej podtitul znie Prechod zo vzdelávania a starostlivosti v ranom detstve do primárneho vzdelávania. $V$ tejto správe ide o identifikáciu faktorov „hladkého“ prechodu na primárne vzdelávanie. V správe prekvapí kritika termínu „scholarizácia“ (schoolification), čím sa správa explicitne vymedzuje voči čistému 
18 pripodobňovaniu sa predškolského sektora sektoru primárneho vzdelávania. Oproti tomu sa skôr rozvíja koncept „pripravenosti na školu“ (school readiness), ktorá rozširuje úzky inštitucionalistický pohlad. Tento diskurzívny konštrukt však nemá oporu v navrhovaných opatreniach, kde sa skôr sleduje scholarizačný a inštitucionalizačný smer. Napr. ide o uvádzanie príkladov krajín, kde sa inštitúcie predškolského vzdelávania stali súčast'ou školskej sústavy, kde zodpovednost' za riadenie sektora leží na ministerstve školstva (OECD, 2017, s. 22), kde prišlo k úprave predškolských kurikúl smerom ku kontinuite s kurikulami primárneho vzdelávania, či dokonca v súlade s primárnym vzdelávaním k zarad'ovaniu nových predmetov alebo vzdelávacích oblastí do predškolských kurikúl (s. 27). Zatial' čo od správy Starting Strong II bola propagovaná myšlienka systémovej a kurikulárnej integrácie sektorov 0-3 a 3-6, v tejto správe nachádzame ako riešenie zabezpečenia kontinuity s primárnym vzdelávaním aj tvorbu „integrovaného národného kurikulárneho rámca“ (s. 28) obsahujúceho tak predškolské ako aj primárne vzdelávanie. Zároveň, ako jedno z riešení hladkého prechodu sa uvádzajú príklady zpovinnenia minimálne časti vzdelávania na predprimárnom stupni (s. 46-47).

Vrcholom monitorovacej a normalizačnej snahy OECD je prvé globálne medzinárodné testovanie pät'ročných predškolákov, ktoré OECD začalo implementovat' od roku 2016. Kritickí akademici označili toto testovanie ako „Baby PISA“ (Pence, 2016), teda predškolskú obdobu medzinárodného testovania PISA realizovaného OECD u 15-ročných žiakov. OECD k tomuto testovaniu vydala brožúru s názvom Early Learning Matters (OECD, 2018a). Už v úvode otec testovania PISA, Andreas Schleicher, uvádza, že ciel'om tohto nového testovania, nazvaného International Early Learning and Child Well-Being Study (IELS), je zlepšenie výsledkov predškolského vzdelávania. Toto zlepšenie sa vníma najmä vo väzbe na neskoršiu lepšiu úspešnost' v testovaní PISA. Tomuto vzt’ahu sa venuje celá druhá kapitola brožúry. Priamo sa tu hovorí o „meniacej sa úlohe VSRD“, ktorá už nespočiva len v podpore zamestnanosti matiek (diskurz ženských práv resp. rodový diskurz), ale aj v zlepšovaní vzdelávacích výsledkov detí. To, že VSRD má aj iné úlohy a funkcie, brožúra netematizuje.

Tretia kapitola už približuje nové testovanie predškolákov, ktorého výsledky boli zverejnené v roku 2020. Pripomeňme, že deti boli testované v štyroch doménach (vynárajúca sa jazyková gramotnost', vynárajúca sa matematická gramotnost', sebaregulačné schopnosti, sociálne a emocionálne zručnosti). Podobne ako pri testovaní PISA sa aj pri testovaní IELS zhromažd'ovali kontextové údaje a to najmä formou dotazníkov pre učitel'ov a rodičov detí. Posudzovanie výkonu diet'at'a v daných štyroch doménach realizoval externý administrátor prostredníctvom vyhodnocovania úloh, ktoré diet'a rieši na tablete. Riešenie úloh z jednej domény diet’at'u zaberie približne 15 minút a takto môže za deň absolvovat' maximálne dve domény.

Tvrdá kritika (napr. Urban, 2018; Auld \& Morris, 2019) redukovanej, na výkon orientovanej predstavy raného vzdelávania, zavádzania prvkov štandardizovaného testovania $v$ ranom detstve, ignorovania kontextov raného vzdelávania či diverzity detskej populácie $v$ inštitúciách raného vzdelávania ovplyvnila skutočnost', že zo 16 krajín zúčastnených na prípravnej fáze projektu, sa prvého kola testovania 
zúčastnili len tri krajiny - Anglicko, USA a Estónsko. Vel'kí hráči ako Nemecko, Francúzsko či Japonsko sa nateraz z tejto iniciatívy stiahli. Je však nesporné, že rankingy a analýzy, ktoré na základe uvedeného testovania OECD začne publikovat', ovplyvnia politiky predškolského vzdelávania a vzdelávacie transfery v mnohých krajinách.

Príklon k silne redukovanej, ekonomizovanej, technokratickej a na výsledky orientovanej predstave vzdelávania $v$ ranom detstve nachádzame $v$ množstve d’alších dokumentov, ktoré OECD v ostatnom roku doslova chrlí. Ide napr. o dva pracovné materiály (Shuey \& Kankaraš, 2018; Shuey et al., 2019) podporujúce silný monitoring raného vzdelávania, orientáciu na vzdelávacie výsledky a napojenie na primárne vzdelávanie, ale aj o publikáciu o ranom vzdelávaní, ktorej autorom je sám Andreas Schleicher (2019) a ktorá sa osobitne zaoberá napr. raným detstvom a informačno-komunikačnými technológiami.

\subsection{Európska únia}

EÚ už okrem mäkkých foriem regulácie môže uplatňovat' mechanizmus tvorby smerníc a záväzných odporúčaní spojených so sankčnými a d’alšími regulačnými (napr. rozpočtovými) opatreniami. Otázky raného vzdelávania však spočiatku neboli zo strany EÚ riešené cez tento typ regulácie. Už v roku 1987 Európska komisia iniciovala vznik Siete starostlivosti o deti (Childcare Network), ktorú tvorila skupina odborníkov a autorít $v$ tomto sektore. Vyústením snahy o uchopenie problematiky raného detstva na európskej úrovni bolo Council Recommendation of 31 March 1992 on Child Care (Council of the European Union, 1992). V tomto odporúčaní, ktoré nemá záväzný charakter, no členské krajiny sú do troch rokov od jeho prijatia povinné informovat' o opatreniach smerujúcich k naplneniu uvedených odporúčaní, sleduje EÚ predovšetkým ciel' efektívnej podpory zladenia rodinného a pracovného života a skorého návratu matiek do zamestnania (rodový diskurz a zamestnávatel'ský diskurz). S tým súvisí ciel' dostupnej (z hl'adiska hustoty siete) a pre rodičov dosiahnutel'nej (z hladiska nákladov) ranej starostlivosti.

Úplne iný charakter má správa Quality Targets in Services for Young Children. Proposals for a Ten Year Programe (Childcare Network, 1996), ktorú pod gesciou EÚ v roku 1996 publikovala už spomínaná siet’ odborníkov z oblasti ranej starostlivosti. 40 stanovených cielov totiž nesmeruje len k podpore rodín a politikám zamestnanosti žien. Správa sa zaoberá aj prínosom takejto starostlivosti pre deti (rozvojový diskurz) a taktiež profesionalizáciou sektora. Otvára aj otázku kvality ranej starostlivosti. Prosperovanie detí vo všetkých oblastiach svojho rozvoja (nielen kognitívnej) má byt' základom kvalitných služieb ranej starostlivosti, bez ohl'adu na profesijný status rodičov, kultúrne rozdiely či špecifické potreby. Rané vzdelávanie má byt' dostupné všetkým. Prioritou pritom nemá byt' vzt'ah inštitúcií raného vzdelávania k neskoršej školskej dochádzke ale aktuálne (nie nevyhnutne na budúcnost' orientované) prosperovanie a zlepšovanie kvality života detí. Tento ciel' je v danej správe špeciálne vyzdvihnutý. Pri jednotlivých ciel’och sa v správe uvádzajú príklady najlepších praxí z vybraných krajín. Často sa uvádza Španielsko, Taliansko či Dánsko. 
K zásadnému obratu $\mathrm{v}$ záujme o rané detstvo a $v$ jeho koncipovaní dochádza naštartovaním tzv. Lisabonskej stratégie v roku 2000, ktorá chápe vzdelávanie ako prostriedok ekonomického rozvoja $v$ informačnej a vedomostnej spoločnosti. Lisabonská stratégia smeruje k rozvoju „ekonomiky založenej na poznatkoch“ (European Council, 2000), čím prioritizuje ekonomickú funkciu vzdelávania a chápe ho ako základný prostriedok rozvoja „humánneho kapitálu“. V oznámení Education \& Training 2010 s podtitulom The Success of the Lisbon Strategy Hinges on Urgent Reforms (Commission of the European Communities, 2003) je prepojenie vzdelávania a ekonomickej racionality posilnené avizovaným zriadením expertnej skupiny posudzujúcej národné vzdelávacie politiky z ekonomickej perspektívy. Takýto projekt sa v správe označuje ako projekt Ekonómie vzdelávania, ktorý v roku 2004 vyústil do zriadenia Európskej siete expertov na ekonómiu vzdelávania (The European Expert Network on Economics of Education). Táto siet' vypracovala analytickú správu, ktorá bola podkladom k oznámeniu Európskej komisie s názvom Efektívnost' a rovnost' $v$ európskych systémoch vzdelávania a odbornej prípravy (Komisia európskych spoločenstiev, 2006).

Toto oznámenie je klúčové z viacerých dôvodov. Prvým je, že sa konceptuálne rozchádza s predstavou predškolského vzdelávania a raného detstva prítomnou v dokumentoch EÚ z devät'desiatych rokov 20. storočia. Väzbu raného vzdelávania na rodinu, zamestnanost' žien a na prosperovanie a blaho detí strieda predstava raného vzdelávania ako efektívneho nástroja hospodárskeho rastu a zamestnanosti. Zdôrazňuje sa jeho prospektívne utilitárny význam. V oznámení sa prvýkrát objavuje poukaz na najvyššiu ekonomickú návratnost' a efektívnost' investícií do predškolského vzdelávania v porovnaní s vyššími stupňami vzdelávania (Komisia európskych spoločenstiev, 2006, s. 3-5). Toto konštatovanie bude neustále opakované v nasledujúcich dokumentoch únie. Zároveň sa v tomto dokumente prvýkrát objavuje predškolské vzdelávanie ako funkčný prvok celoživotného vzdelávania. V oznámení sa predškolské vzdelávanie dokonca stáva klúčovým prvkom sociálnych politík a to najmä z ekonomického pohl'adu: „Nedostatok investícií do včasného vzdelávania vedie $\mathrm{k}$ podstatne vyššej úrovni výdavkov na nápravu v neskorších etapách života, čo je menej nákladovo efektívne a môže sa spájat' so zvýšenými výdavkami v oblasti kriminality, zdravotníctva, nezamestnanosti a iných sociálnych politík“ (s. 5). Jones (2010) uvádza, že práve v tomto období a na základe týchto (a nasledujúcich) dokumentov vzniká prvý dlhodobejší politický konsenzus $v$ nasmerovaní vzdelávacích politík $v$ rámci EÚ. Táto zmena pohl'adu dostala EÚ a jej orgány do centra diskusií o vzdelávacích reformách $v$ jednotlivých členských štátoch. Podla neho tak došlo k „europeizácii vzdelávacích politík a politík odbornej prípravy“ (Jones, 2010, s. 374).

Vzdelávanie, a najmä to predškolské, sa odteraz nielenže dostáva do centra spoločenskej správy a politík, ale od tohto oznámenia zároveň prestáva byt' vnímané ako náklad, alebo výdavok, ale zrkadlí sa $v$ ňom nové vnímanie vzdelávania ako sociálnej investície. Možno hovorit’ o novej „sociálno-investičnej paradigme“ (Hemerijck, 2016, s. 190) vnímajúcej prípravu indivíduí na poznatkovú ekonomiku cez investície do humánneho kapitálu a kapacít počnúc predškolským vzdelávaním. 
Sociálno-investičná paradigma sa dištancuje od tradičných fiškálnych úsporných opatrení tvrdiac, že aktívne sociálne politiky tlačia na ekonomický rast a kompetitívnost', čím sa redukujú dlhodobé fiškálne tlaky (Hemerijck, 2016, s. 191). Typické je prospektívne nastavenie tejto paradigmy - sociálne výdavky sa chápu v tesnej väzbe na budúce benefity. Základné východisko je pripravovat' a nie opravovat' (prepare rather than repair) (Morel et al., 2012, s. 13). Tento preventívny model vyžaduje vyššiu angažovanost' verejného sektora $v$ ranom vzdelávaní, čo priamo podporuje de-familializované vnímanie raného detstva a silnejšiu väzbu na prospektívnu školskú úspešnost' (Casalini, 2014).

Tento model preberá a uplatňuje aj na Lisabonskú stratégiu nadväzujúca stratégia Európa 2020 (Európska komisia, 2010), ktorá v oblasti vzdelávania sleduje tzv. strategický rámec pre európsku spoluprácu vo vzdelávaní a odbornej príprave, v skratke ET 2020 (Rada Európskej únie, 2009). V danom strategickom rámci spolupráce sa ešte viac upevňuje vplyv EÚ na národné vzdelávacie politiky cez posilnenie tzv. otvorenej metódy koordinácie (OMC) založenej na vzájomnom učení sa členských štátov v prioritných oblastiach, širení výsledkov, periodických správach o pokroku a monitorovacích procesoch (Rada Európskej únie, 2009, s. 5). Tento rámec stanovuje Európske referenčné hodnoty pre vybrané oblasti v sektore vzdelávania. Vero (2012) porovnal vzdelávacie indikátory stanovené Lisabonskou stratégiou s tými, ktoré stanovila stratégia Európa 2020. Jeho záver je jednoznačný: „Zameranie na vzdelávanie v ranom detstve je najväčšou inováciou v ET 2020“ (Vero, 2012, s. 3). Snaha extenzívnejšie riadit' a reglementovat' oblast' VSRD sa tu ešte výrazne posilňuje.

$\checkmark$ danej intencionalite vzniká oznámenie Európskej komisie s príznačným názvom Vzdelávanie a starostlivost' $v$ ranom detstve: zabezpečenie optimálneho začiatku pre všetky naše deti vo svete budúcnosti (Európska komisia, 2011), ktoré sa zaoberá výhradne raným vzdelávaním a starostlivost'ou. Diskurz dokumentu je v súlade so sociálno-investičnou paradigmou stratégie Európa 2020. Silnejšie sa v ňom akcentuje vzt’ah raného vzdelávania a vyššej kvalifikovanosti pracovnej sily a vzt’ah k lepším vzdelávacím výsledkom na konci nasledujúcich vzdelávacích cyklov:

VSRD hrá podstatnú rolu pri položení základov lepších spôsobilostí budúcich občanov EÚ, čo nám umožňuje riešit' strednodobé a dlhodobé výzvy a vytvorit' kvalifikovanejšiu pracovnú silu, ktorá je schopná prinášat' svoj vklad a prispôsobovat' sa technologickým zmenám... Existujú jasné dôkazy o tom, že účast' na vysoko kvalitnom VSRD vedie $\mathrm{k}$ významne lepším výsledkom v medzinárodných testoch základných schopností akými sú napr. PISA a PIRLS, ktoré zodpovedajú pokroku za jeden až dva roky školskej dochádzky. (Európska komisia, 2011, s. 3)

Okrem toho, že prvýkrát dochádza k tematizácii vzt’ahu s medzinárodnými testovaniami vzdelávacích výsledkov, vyjadruje sa aj snaha koordinovat' otázky VSRD na celoeurópskej úrovni. Pripomína sa tu vyššie spomenutá otvorená metóda koordinácie (Európska komisia, 2011, s. 5) zo strany EÚ. V dokumente sa tieto snahy zhmotňujú najmä v otázke financovania sektora a zabezpečovania kvality VSRD, ktorá sa poníma vo väzbe na tvorbu učebných osnov, personálne podmienky VSRD a riadenie VSRD. 
22 Oznámenie na prvý pohlad oslabuje kognitivistické zameranie sociálno-investičnej paradigmy VSRD konštatovaním, že pre rozvoj diet'at’a sú potrebné aj „nekognitívne schopnosti“ (Európska komisia, 2011, s. 9). Ked’ sa však pozrieme, čo sa myslí pod takýmito schopnost’ami (vytrvalost', motivácia, schopnost' vstupovat' do kontaktu $s$ inými a udržiavat' tieto kontakty), je jasné, že ide o schopnosti extrafunkcionálnej kvalifikácie - bazálne schopnosti potrebné pre pracovnú činnost’ a zaradenie sa do pracovných kolektívov. Takže rozhodne nemôžeme tvrdit', že uvedený dokument hovorí o všestrannom rozvoji detí zohl'adňujúc napr. emocionálny rozvoj, rozvoj estetického vnímania a cítenia a pod. a že by teda sledoval rozvojovú paradigmu. Oznámenie sa taktiež vôbec nezmieňuje o detských právach.

$\checkmark$ roku 2013 prichádza d’alší dokument, tentoraz odporúčanie Komisie s názvom Investovat' do detí: východisko z bludného kruhu znevýhodnenia (Európska komisia, 2013). Sociálno-investičná paradigma je prítomná už v samotnom názve odporúčania. Dokument je však v porovnaní s predchádzajúcim oznámením vyváženejší, najmä (proklamatívnym) zdôrazňovaním VSRD vo väzbe na detské práva a kvalitu života samotných detí. V dokumente však uvedené dimenzie nie sú d’alej rozvinuté prostredníctvom návrhov efektívnych postupov či príkladov. Kladie sa skôr dôraz na efektívnu správu sektora cez návrh „monitorovacieho rámca“ uvedeného v prílohe odporúčania. Monitorovací rámec tvoria formálne analytické ukazovatele (napr. miera rizika chudoby, materiálnej deprivácie a pod.) aplikovatel'né na príslušnú detskú populáciu. Ide teda o deskriptívne ukazovatele, ktoré môžu tvorit' podklad sociálnych politík, ale samé o sebe nepodporujú zabezpečovanie detských práv a ani nezvyšujú kvalitu života detí. Typickým pre tento dokument je teda monitorovanie ako základný inštrument efektívneho investovania.

Úplne jednoznačným produktom sociálno-investičnej paradigmy sú Závery Rady o úlohe vzdelávania $v$ ranom detstve a primárneho vzdelávania pri podpore tvorivosti, inovačnosti a digitálnej kompetencie (Rada Európskej únie, 2015). Tu už je rané vzdelávanie chápané ako nevyhnutný segment investovania do humánneho kapitálu smerom k budovaniu digitálneho hospodárstva (Rada Európskej únie, 2015, s. 17). Za účelom prípravy efektívnych pracovníkov budúcnosti treba už v predškolských inštitúciách použivat' „digitálne nástroje s pedagogickou hodnotou“ (s. 18) a tomuto cielu prispôsobit' celkové vzdelávanie, profesijnú prípravu ako aj d’alšie vzdelávanie učiteliek v predškolských inštitúciách.

Po dokumentoch typu odporúčaní, oznamov a záverov pristúpila EÚ aj k tvorbe analytických dokumentov. $\mathrm{V}$ roku 2014, takže po 18 rokoch od poslednej správy Quality Targets in Services for Young Children sa EÚ opät' vracia k otázke kvality VSRD, kvality, ktorá je však redefinovaná v nadväznosti na sociálno-investičnú paradigmu Lisabonskej stratégie s dôrazom na riadiacu a monitorovaciu činnost'. Správu s názvom Proposal for Key Principles of a Quality Framework for Early Childhood Education and Care (European Commission, 2014) vypracovala pracovná skupina pre VSRD zriadená Európskou komisiou. Ide o prehl'adovú a komparatívnu správu porovnávajúcu rôznorodé, najmä štrukturálne aspekty kvality VSRD vo vybraných krajinách EÚ. V tomto je najväčší rozdiel oproti správe z roku 1996, ktorá sa zaoberala 
aj procesuálnymi aspektmi kvality. Zatial' čo starší dokument explicitne rieši proces vzdelávania a vzdelávacích ciel'ov, novší dokument si vystačí s pojmom kurikulum, ktorý chápe ako štrukturálny rámec VSRD. Podobne ako v staršom dokumente, tak aj tu sa použivajú príklady jednotlivých európskych krajín. Opät', ide najmä o príklady systémových rámcov (zabezpečovania dostupnosti, profesijnej prípravy, monitorovacích rámcov). Používajú sa pritom príklady najmä krajín s unifikovanými rámcami, alebo krajín, kde vnútroštátnu diferenciáciu nahrádza snaha o celonárodnú koordináciu (napr. Nemecko). Krstovic a Drakulic (2019, s. 44) preto uvádzajú, že „rámce kvality politiky VSRD sú nad’alej zamerané na sociálne, vonkajšie aspekty..., sociálne a ekonomické argumenty prevládajú nad tými, ktoré sa zaoberajú vzdelávaním“.

V roku 2018 vzniká dokument Monitoring the Quality of Early Childhood Education and Care - Complementing the 2014 ECEC Quality Framework Proposal with Indicators (European Commission, 2018). Dokument pokračuje v logike predchádzajúceho návrhu, no poskytuje 22 deskriptívnych ukazovatel'ov, ktoré v dôsledku umožňujú porovnávanie medzi členskými krajinami. Dátové podklady tak môžu tvorit' základ mäkkých regulačných procesov v rámci EÚ, ktoré v tomto sektore už viac ako desat' rokov uplatňuje OECD. Práve takéto typy porovnaní spravidla tvoria podklad pre vzdelávacie výpožičky. Dokument pri jednotlivých indikátoroch ukazuje aj tzv. prípadové štúdie, čiže príklady z vybraných krajín. Dokument teda prináša nielen operacionalizovanú predstavu kvality v rámci VSRD, ale aj vytvára platformu pre porovnávanie členských krajín v rámci zvolených indikátorov a teda aj podmienky pre efektívnejšiu globálnu reguláciu národných systémov.

Dynamiku, s akou sa EÚ vyjadruje k otázkam VSRD, demonštrujú nasledujúce legislatívne snahy, ktoré priamo vyplývajú z vyššie uvedených správ. Ide najmä o Odporúčanie Rady týkajúce sa vysokokvalitných systémov vzdelávania a starostlivosti $v$ ranom detstve (Európska komisia, 2018a). Už v úvode dokumentu je zdôraznené prospektívne vnímanie VSRD najmä vo väzbe na vzdelávacie výsledky a testovanie PISA. Poukaz o najväčšej návratnosti investícií tu taktiež nachádzame. Cielom dokumentu je „stanovit' spoločné európske chápanie toho, čo predstavuje kvalitu vo vzdelávaní a starostlivosti v ranom detstve“ (Európska komisia, 2018a, s. 2). Tomu slúži príloha odporúčania, ktorá obsahuje „rámec kvality EÚ pre vzdelávanie a starostlivost' v ranom detstve“. Ten pozostáva z desiatich „vyhlásení o kvalite“, ktoré sú prevzaté zo správy doplňujúcej návrh rámca kvality o indikátory. Ide tu o všeobecné proklamácie týkajúce sa poskytovania služieb VSRD, pracovníkov a pracovných podmienok v sektore, učebných plánov, hodnotenia a monitorovania VSRD a riadenia a financovania VSRD.

No a na koniec tu máme správu Európskej komisie $O$ rozvoji zariadení starostlivosti o malé deti na účely zvýšenia účasti žien na trhu práce, zabezpečenia rovnováhy medzi pracovným a súkromným životom pracujúcich rodičov a zaistenia udržatel'ného a inkluzívneho rastu v Európe (Barcelonské ciele)(Európska komisia, 2018b). Už z názvu tejto správy je zjavné ekonomizované chápanie VSRD. Správa svojím charakterom (členenie, argumentácia, porovnávanie) vel'mi pripomína správy OECD zo série Starting Strong. Nie náhodou sú dokumenty OECD aj v správe často citované, 
24 používané sú taktiež údaje z databáz OECD. Okrem porovnávacích údajov aj tu nachádzame príklady vybraných členských krajín EÚ. Tematizované sú napr. komplexné systémy starostlivosti o deti (Dánsko, Belgicko), či príklady komplexnej bezplatnej starostlivosti o deti (Malta).

\section{Nový koncept a funkcie predškolského vzdelávania}

Z vyššie uvedeného vývoja diskurzu dvoch významných globálnych hráčov možno odvodit' paradigmatickú zmenu v tematizovaní predškolského vzdelávania či VSRD, ktorá sa udiala zhruba pred desiatimi rokmi a následnými dokumentmi a rozhodnutiami bola neustále posilňovaná. Zhruba od tohto obdobia obe organizácie prostredníctvom svojich dokumentov demonštrujú aj regulačné a globalizačné snahy.

OECD zhruba už od druhej správy zo série Starting Strong smeruje k odporúčaniu centrálnej koordinácie a administratívnej integrácie celého sektora VSRD. Postupne sa pridáva zdôrazňovanie silnejúcej väzby na primárne vzdelávanie, štandardizácia a orientácia na vzdelávacie výsledky, či snaha o tvorbu komplexných systémov monitoringu sektora, aby sa zabezpečovala efektívnost' investícií. Tá vrcholí snahou o monitoring vzdelávacích výsledkov vo forme testovania IELS. OECD prepája význam VSRD s teóriou humánneho kapitálu a chápe VSRD ako ekonomický prostriedok hospodárskeho rozvoja.

EÚ buduje diskurz svojich dokumentov o VSRD cez stratégiu ekonomickej konkurencieschopnosti krajín EÚ známou ako Lisabonská stratégia. Tá posúva vnímanie predškolského vzdelávania smerom k sektoru národného hospodárstva, do ktorého sa oplatí investovat'. VSRD sa stáva centrom tzv. sociálno-investičnej paradigmy EÚ. V týchto dokumentoch nie je akcentovaná saturácia aktuálnych vývinových potrieb detí, ale príspevok k ich budúcej školskej a pracovnej úspešnosti. Od toho sa odvíja aj snaha definovat' celoeurópske indikátory kvality VSRD, ktoré umožnia efektívne porovnávanie medzi členskými krajinami a naštartujú procesy „europeizácie“ sektora.

Aktuálne vnímanie VSRD zo strany OECD a EÚ vykazuje konvergujúcu tendenciu. Obe sa rozchádzajú s pedagogickým vnímaním sektora typickým pre druhú polovicu devät'desiatych rokov 20. storočia $v$ prípade EÚ či prelomom nového milénia $v$ prípade OECD. Obe smerujú k unifikácii a štandardizácii sektora cez koncept kvality, jeho indikátorov a ich monitoringu tak, aby sa sektor VSRD stal lepšie regulovatel'nou oblast'ou sociálnej politiky za účelom stimulovania jeho ekonomických a hospodárskych benefitov. Diet'a sa vníma prizmou jeho potenciálneho prínosu $v$ neskoršom živote, z hl'adiska jeho potenciálnych kapacít naplnit' spoločenské očakávania najmä $\checkmark$ oblasti trhu práce a novej poznatkovej ekonomiky.

V dokumentoch EÚ však možno vnímat' isté konceptuálne pnutie, ktoré v prípade OECD nie je tak evidentné. Ešte aj v roku 2013 sa objavujú snahy nestratit' spojenie VSRD s konceptom detských práv (diskurz detských práv) a kvalitou života detí (rozvojový diskurz). Tieto ojedinelé prípady ukazujú základný paradigmatický 
konflikt medzi predchádzajúcimi prístupmi a „štrukturálne funkcionalistickým“ (Krstovic \& Drakulic, 2019, s. 45) prístupom zameraným na sociálne investície. Každý z týchto prístupov vytvára špecifickú sociálnu konštrukciu detí a raného detstva (Olk, 2010).

Prístup zameraný na detské práva či rozvojový prístup podnecuje na diet’a zameranú konštrukciu tak, ako ju často nachádzame v akademických textoch kritických štúdií detstva (Kašparová \& Klvaňová, 2016). Tá vníma špecifiká detského života, vníma detstvo ako svojbytnú fázu života s vlastnou kvalitou a významom samým o sebe. Stotožňujeme sa však s názorom Daly (2019), že aj ked' táto perspektíva má akademicky vel'mi významný vplyv, nemá dopad na tvorbu európskych sociálnych politík. Daly prezentuje analytický model, ktorý zohladňuje tri možné prístupy sociálnych politík k det’om. Prvým je prístup orientovaný na rodinu s primárnym zameraním na dospelých, s nepriamym vzt'ahom s det'mi, podporujúci rodinu a jej príjem. Druhý je prístup orientovaný na detstvo zameriavajúci sa na dospelých, s priamym aj nepriamym vzt'ahom s det'mi, kde ciel'om sú dostatočné zdroje v detstve a príprava na dospelý život. Tretí prístup je prístup orientovaný na deti zameriavajúci sa aj na deti a aj na dospelých, s priamym vzt'ahom s det'mi, vnímajúci deti ako svojbytnú skupinu s vlastnými potrebami, podporujúci služby pre deti a zabezpečovanie zdrojov pre deti. Dnes sa dominantným stáva druhý prístup, ktorý zodpovedá sociálno-investičnej paradigme. V tomto prístupe „sa však väčšinou opomína aktuálne prosperovanie diet'at’a, detské práva a participácia a vzdelávanie detí“ (Casalini, 2014, s. 78).

OECD a EÚ tak vytvárajú špecifický, pomerne jednostranný globálny diskurz o ranom detstve a predškolskom vzdelávaní, ktorý cez rôzne regulačné kanály ovplyvňuje reformy $v$ jednotlivých štátoch. $V$ prípade VSRD možno $v$ ostatných desiatich rokoch hovorit' o nasledovných tendenciách vyplývajúcich z nového globálneho diskurzu: zvýšená verejná kontrola inštitúcií VSRD najmä cez vyhodnocovanie ich úrovne a kvality; globálne revízie a homogenizácie kurikúl VSRD; a silnejšie viazanie inštitúcií VSRD na školskovzdelávací sektor (schoolification).

V nasledujúcej časti ukážeme, ako sa tieto tendencie a s nimi spojený prevládajúci sociálny konštrukt VSRD prejavil v reformách sektora $v$ dvoch členských krajinách EÚ - Slovenska, ako novej členskej krajiny s dlhodobou centralizovanou a unifikovanou tradíciou VSRD a Nemecka, klúčového hráča EÚ s decentralizovanou a vel'mi diferencovanou geografiou VSRD.

\section{Globálne politiky v národných implementáciách}

Na Slovensku sa všetky vyššie uvedené tri tendencie udiali paralelne. Vzt'ah predškolského sektora k školskému sektoru sa upevnil tým, že na základe školského zákona z roku 2008 stratili predškolské inštitúcie špecifický status tzv. školských zariadení, ktorý mali dovtedy, a nadobudli status škôl. Stali sa teda rovnocennými prvkami školského systému a upevnil sa tým ich vzt’ah s vyššími stupňami vzdelávania. Zmenou statusu sa aj predškolských inštitúcií začali týkat' rovnaké pravidlá kurikulárneho 
26 plánovania a tvorby kurikula ako v prípade základných škôl. Homogenizovala sa tak základná štruktúra kurikúl všetkých stupňov vzdelávania vrátane raného vzdelávania.

A nešlo len o štrukturálnu homogenizáciu. Ako základný prvok definovania obsahu vzdelávania boli zavedené tzv. vzdelávacie štandardy. Tie majú v národnom kurikule dve podoby, tzv. obsahové štandardy a tzv. výkonové štandardy. Výkonové štandardy presne definujú pozorovatel'né a vyhodnotitel'né výkony a prejavy správania diet'at'a. Takže nejde $v$ tomto prípade len o kurikulárnu homogenizáciu s vyššími stupňami vzdelávania, ale aj o sprehl'adnenie kontroly nad výstupmi zo vzdelávania. Cez vzdelávacie štandardy sa lepšie uplatňuje verejná kontrola nad tým, čo sa deti učia v predškolských inštitúciách. Tieto pohyby vyústili v novej verzii štandardizovaného národného predškolského kurikula na Slovensku, platného od roku 2016 a taktiež k diskusiám o spovinnení predškolského vzdelávania v SR.

Nový štátny vzdelávací program už nemusel reagovat' na štrukturálnu homogenizáciu, ktorá sa udiala už v roku 2008. Reagoval však na obsahové aspekty predškolského vzdelávania, v rámci ktorých sa implementoval nový obsah vzdelávacích oblastí tak, ako sa to deje $v$ krajinách často uvádzaných ako vzorových v správach OECD a EÚ. Napr. sa zmenila koncepcia prírodovedného vzdelávania a do istej miery aj koncepcia jazykovej gramotnosti - oblastí, ktoré sa v sociálno-investičnej paradigme tematizujú ako klúčové pre d’alší školský úspech a pre hospodársky rast.

Autorský kolektív programu vykonal taktiež cielenú výpožičku na úrovni štruktúry národného kurikula. Podla vzoru Nového Zélandu a nemeckej spolkovej republiky Sasko-Anhaltsko zaradil do ŠVP čast' Evaluačné otázky. Tie umožňujú učitelom monitorovat' priebeh učenia sa detí a lepšie sledovat' kvalitu vzdelávacieho procesu.

Nemecko bola jednou z prvých krajín, ktorá v rámci EÚ iniciovala reformy a zmeny v chápaní VSRD. Urýchl'ovačom tejto angažovanosti bol tzv. PISA šok v roku 2001, ktorý okamžite rozprúdil v Nemecku diskusiu o význame a funkciách raného vzdelávania (Olk, 2010). Zlyhanie v testovaní 15-ročnej populácie bolo dávané do vzt’ahu $\mathrm{k}$ roztrieštenému systému raného vzdelávania. V Nemecku tak nastal bezprecedentný vývoj, ktorý mapujú aj porovnávacie kurikulárne štúdie založené na diskurzívnej analýze (Fangmeyer \& Kaščák, 2016).

V Nemecku sa po roku 2001 otvorila debata o scholarizácii VSRD. Nemecký príklad je zaujímavý tým, že sektor VSRD je tradične autonómnym sektorom spadajúcim pod správu sektoru sociálnych vecí, naviac v kontexte vel'mi decentralizovanej správy federálneho štátu. Tradične sa v ňom nepracuje s myšlienkou väzby na vzdelávanie či školu, čo vyjadruje aj dôraz na iné formatívne procesy ako je len vzdelávanie (Bildung). Tradične ide o výchovu/socializáciu (Erziehung) a starostlivost' (Betreuung) (Frindte \& Mierendorff, 2017). Tradícia a identita sektora tak leží mimo oblasti školstva.

V roku 2004 sa dohodlo všetkých 16 spolkových krajín Nemecka na schválení prvého spoločného rámcového dokumentu týkajúceho sa VSRD (Ständige Konferenz der Kultusminister der Länder in der Bundesrepublik Deutschland, 2004). Diskurzívne je dokument zaujímavý tým, že inštitúcie VSRD sa tu už chápu ako vzdelávacie inštitúcie, čím sa diskurzívne narúša tradičná, neoddelitel'ná dvojica „Bildung“ 
a „Erziehung“ (Frindte \& Mierendorff, 2017). Spôsobilosti diet'at'a nadobudnuté $\checkmark$ predškolskej inštitúcii sú $v$ tomto dokumente tematizované ako kompetencie vo väzbe na kompetenčné rámce EÚ. Vzt’ah k primárnemu vzdelávaniu a lepšej zaškolitel'nosti je $v$ danom dokumente špeciálne zdôraznený. Dokument zároveň stanovuje šest' odporúčaných vzdelávacích oblastí, ktorých by sa mal pridržiavat' obsah vzdelávania v inštitúciách VSRD jednotlivých spolkových krajín. Prvýkrát je tak nastolený proces kurikulárnej koordinácie medzi spolkovými krajinami a zároveň odštartovaný proces tvorby nových kurikúl VSRD jednotlivých spolkových krajín.

Nasledujúci vývoj kurikúl $v$ jednotlivých spolkových krajinách naznačuje zásadnú zmenu. Nové kurikulá vo všetkých spolkových krajinách venujú špecifický dôraz rozvoju jazykových kompetencií a prírodovedno-technických kompetencií diet'at'a (Gisbert, 2004). Schreiber (2009, s. 434) ukazuje, že v troch analyzovaných spolkových krajinách v skupine učiteliek, ktoré sa intenzívne zaoberali novým kurikulom, sa významne zvýšila pozornost' venovaná rozvoju jazykových kompetencií a matematicko-prírodovedných kompetencií detí. Zároveň ukazuje, že stále väčšia skupina rodičov požaduje intenzívnejšiu väzbu predškolských inštitúcií na školu a hladký prechod na primárny stupeň. Možno tak konštatovat', že súčasná VSRD v Nemecku prešla do fáze scholarizácie. Zároveň je potrebné povedat', že tým dochádza aj ku kvalitatívnej zmene raného detstva. $v$ Nemecku došlo $k$ de-familiarizácii raného detstva, $\mathrm{k}$ homogenizácii raného detstva a $\mathrm{k}$ politickej optimalizácii raného detstva (Mierendorff, 2014).

\section{Záver}

Vývoj nadnárodného diskurzu o predškolskom vzdelávaní a aj národných politík naň naviazaných naznačuje zásadnú zmenu dôrazu v ponímaní VSRD a jej sociálnych funkcií. Predchádzajúce diskurzy strieda sociálno-investičná paradigma. S tým súvisí presun dôrazu od zabezpečovania momentálneho prosperovania a blahobytu diet'at'a smerom $\mathrm{k}$ jeho budúcemu rozvoju a príspevku k rozvoju spoločnosti. Analyzované diskurzy teda dôsledne zdôrazňovali prospektívnu funkciu VSRD. Tento budúci príspevok má podobu bud' lepšej úspešnosti v školskom prostredí, v podpore zamestnanosti alebo v príspevku k potenciálne sa objavujúcim segmentom trhu - poznatkovej ekonomiky či digitálneho hospodárstva. Preto sa aj v dokumentoch často vyskytuje koncept humánneho kapitálu, ktorý v sebe integruje jednak prospektívne investičnú logiku a aj chápanie vzdelávania a starostlivosti ako procesu akumulácie potenciálne využitel'ných dispozícií a poznatkov. Preto sa aj v dokumentoch o VSRD a národných kurikulách objavujú diskurzy o rozvoji digitálnych či informačných spôsobilostí, ale aj spôsobilostí z oblasti prírodných vied, techniky či matematiky. Posilňuje sa tak línia kognitivisticky zameraného vnímania VSRD, napr. oproti holisticky zameranému vnímaniu VSRD. Zároveň možno vnímat' snahu o silnejšie zviazanie sektora VSRD so školským vzdelávaním a chápat' výstupy z predškolského vzdelávania takmer výhradne ako vzdelávacie výstupy, ktoré sú obdobne testovatelné ako výstupy zo školského 
28 vzdelávania (IELS ako PISA pre predškolákov). VSRD sa v integrovanom zmysle slova začala vo zvýšenej miere tematizovat' ako funkčný prvok hospodárstva, čím sa aj v tomto sektore a diskurze o ňom prejavila súčasná tendencia „ekonomizácie sociálneho“, pre ktorú je typické, že „ekonomické analytické schémy a kritériá rozhodovania sa prenášajú na oblasti, ktoré bud’ nie sú alebo nie sú výhradne ekonomické, alebo sa dokonca vyznačujú úplne inou racionalitou ako je tá ekonomická“ (Lemke, 2001, s. 108). Pre oblast' pedagogiky a oblast' sociálnej starostlivosti je tento prenos dnes viac ako evidentný.

Globálny diskurz o predškolskom vzdelávaní cez vzájomné porovnávania krajín v oblastiach daných indikátorov, cez nástroje kontroly kvality, ale aj cez viaceré spomenuté legislatívne nástroje, zasahuje národné politiky VSRD a nabáda k vzdelávacím reformám a výpožičkám. A ako ukázal príklad Nemecka, a to aj v takých prípadoch, kedy nová konceptualizácia koliduje s tradíciou a tradičnými formami VSRD viazanými na koncept starostlivosti či na vol’ný vzt'ah ku škole. Nejde však len o prípad Nemecka, existujú evidencie o tom, že obdobné pohyby prebiehajú napr. aj v škandinávskych krajinách (Paananen, Lipponen, \& Kumpulainen, 2015; Clausen, 2015), čo možno považovat' za prekvapujúce vzhl'adom na sociálnopedagogickú tradíciu VSRD.

Preto sme už dnes nútení vnímat' obmedzenú platnost' sloganu známej autority VSRD, P. Mossa (2009), že „Existujú alternatívy!“. Ukazuje sa skôr, že na úrovni národných vzdelávacích politík môžeme sledovat’ ubúdanie diverzity v politikách, správe a formách VSRD a že aj pre tento sektor je silne relevantná konvergenčná hypotéza.

\section{Pod'akovanie}

Táto štúdia vznikla s podporou projektov VEGA 2/0134/18, VEGA 1/0258/18, KEGA 009TTU4/2018 a APVV-19-0314.

\section{Literatúra}

Auld, E., \& Morris, P. (2019). The OECD and IELS: Redefining early childhood education for the 21st century. Policy Futures in Education, 17(1), 11-26.

Campbell-Barr, V., \& Bogatić, K. (2017). Global to local perspectives of early childhood education and care. Early Child Development and Care, 187(10), 1461-1470.

Campbell-Barr, V., \& Nygård, M. (2014). Losing sight of the child? Human capital theory and its role for early childhood education and care policies in Finland and England since the mid-1990s. Contemporary Issues in Early Childhood, 15(4), 346-359.

Casalini, B. (2014). The early childhood education and care policy debate in the EU. Interdisciplinary Journal of Family Studies, 19(1), 77-94.

Clausen, S. B. (2015). Schoolification or early years democracy? A cross-curricular perspective from Denmark and England. Contemporary Issues in Early Childhood, 16(4), 355-373.

Commission of the European Communities. (2003). Education \& training 2010. The success of the Lisbon strategy hinges on urgent reforms. COM (2003) 685. Brussels: Commission of the European Communities. 
Council of the European Union. (1992). 92/241/EEC: Council recommendation of 31 March 1992 on child care. Brussels: Council of the European Union.

Daly, M. (2019). Children and their rights and entitlements in EU welfare states. Journal of Social Policy, 49(2), 343-360.

Dos Santos Sousa, D., Grey, S., \& Oxley, L. (2019). Comparative international testing of early childhood education: The democratic deficit and the case of Portugal. Policy Futures in Education, 17(1), 41-58.

European Commission. (2014). Proposal for key principles of a quality framework for early childhood education and care. Brussels: European Union.

European Commission. (2018). Monitoring the quality of early childhood education and care Complementing the 2014 ECEC quality framework proposal with indicators. Brussels: European Commission.

European Council. (2000). Presidency conclusions. Lisbon European Council, 23 and 24 March 2000. http://www.europarl.europa.eu/summits/lis1_en.htm\#.

Európska komisia. (2010). EURÓPA 2020: Stratégia na zabezpečenie inteligentného, udržatel'ného a inkluzívneho rastu. KOM(2010) 2020. Brusel: Európska komisia.

Európska komisia. (2011). Vzdelávanie a starostlivost' v ranom detstve: zabezpečenie optimálneho začiatku pre všetky naše deti vo svete budúcnosti. KOM(2011) 66. Brusel: Európska komisia.

Európska komisia. (2013). Investovat' do detí: východisko z bludného kruhu znevýhodnenia (2013/112/EÚ). Brusel: Európska komisia.

Európska komisia. (2018a). Odporúčanie Rady týkajúce sa vysokokvalitných systémov vzdelávania a starostlivosti v ranom detstve. COM(2018) 271. Brusel: Európska komisia.

Európska komisia. (2018b). Správa komisie Európskemu parlamentu, Rade, Európskemu hospodárskemu a sociálnemu výboru a výboru regiónov o rozvoji zariadení starostlivosti o malé deti na účely zvýšenia účasti žien na trhu práce, zabezpečenia rovnováhy medzi pracovným a súkromným životom pracujúcich rodičov a zaistenia udržatel'ného a inkluzívneho rastu $v$ Európe (Barcelonské ciele). COM(2018) 273. Brusel: Európska komisia.

Fangmeyer, A., \& Kaščák, O. (2016). Transgressionen: Zum diskursiven Rekonfigurieren von institutionalisierten (frühen) Kindheiten. Ein slowakischdeutscher Vergleich von curricularen Dokumenten. In I. Nentwig-Gesemann, I., K. Fröhlich-Gildhoff, T. Betz \& S. Viernickel (Eds.), Forschung in der Frühpädagogik 9 (s. 141-172). Freiburg: FEL.

Frindte, A. , \& Mierendorff, J. (2017). Bildung, Erziehung [education] and care in German early childhood settings - spotlights on current discourses. Journal of Pedagogy, 8(1), 99-120.

Gisbert, K. (2004). Neue Bildungsinhalte. In I. Wehrmann, I. (Ed.), Kindergärten und ihre Zukunft (s. 138-148). Weinheim: Beltz.

Hemerijck, A. C. (2016). Rethinking $E(M) U$ governance from the perspective of social investment. In P. Iglesias-Rodriguez, A. Triandafyllidou, \& R. Gropas (Eds.), The Financial Crisis and Paradigm Shift: Legal, Economic, and Political Perspectives (s. 173-211). London: Palgrave / MacMillan.

Humes, W. (2000). The discourses of educational management. Journal of Educational Enquiry, 1(1), 35-53.

Childcare network. (1996). Quality targets in services for young children. Proposals for a ten year programme. https://www.childcarecanada.org/sites/default/files/Qualitypaperthree.pdf.

Jones, P. (2010). The politics of the economics of education in the European Union. European Educational Research Journal, 9(3), 359-380.

Kašparová, I., \& Klvaňová, R. (2016). Dítě a dětství: proměnlivá konceptualizace pojmů a její vazby na vzdělávání. Sociológia, 48(4), 377-398.

Klimovský, D. (2010). Genéza koncepcie good governance a jej kritické prehodnotenie v teoretickej perspektíve. Ekonomický časopis, 58(2), 188-205.

Komisia európskych spoločenstiev. (2006). Efektívnost' a rovnost'v európskych systémoch vzdelávania a odbornej prípravy. KOM(2006) 481. Brusel: Európska komisia.

Krstovic, J., \& Drakulic, M. (2019). Did Cinderella arrive at the ball? Implications of contemporary European education policies on the prospects of early childhood education and care. International Journal of Humanities Social Sciences and Education, 6(3), 40-49. 
30 Lemke, T. (2001). ,Die Ungleichheit ist für alle gleich“ - Michel Foucaults Analyse der neoliberalen Gouvernementalität. Miszelle, 16(2), 99-115.

Mahon, R. (2009). The OECD's discourse on the reconciliation of work and family life. Global Social Policy, 9(2), 183-204.

Mahon, R. (2016). Early childhood education and care in global discourses. In K. Mundy, A. Green, B. Lingard, \& A. Verger (Eds.), The handbook of global education policy (s. 224-240). Chichester: John Wiley \& Sons.

Malatinská, S. (2014). Kritická historická analýza vplyvu pruského vzdelávacieho systému na americký vzdelávací systém. Pedagogika.sk, 5(2), 122-136.

Mierendorff, J. (2014). Annäherungen von Kindergarten und Schule. Wandel früher Kindheit? In P. Cloos, K. Hauenschild, I. Pieper, \& M. Baader (Eds.), Elementar- und Primarpädagogik. Internationale Diskurse im Spannungsfeld von Institutionen und Ausbildungskonzepten (s. 23-37). Wiesbaden: Springer.

Morel, N., Palier, B., \& Palme, J. (2012). Beyond the welfare state as we know it? In N. Morel, B. Palier, \& J. Palme (Eds.). Towards a Social Investment Welfare State? Ideas, Policies and Challenges (s. 1-30). Bristol: Policy Press.

Moss, P. (2009). There are alternatives! Markets and democratic experimentalism in early childhood education and care. Working papers No. 53. The Hague: Bernard van Leer Foundation.

Moss, P. (2017). Power and resistance in early childhood education: From dominant discourse to democratic experimentalism. Journal of Pedagogy, 8(1), 11-32.

Moss, P., Dahlberg, G., Grieshaber, S., Mantovani, S., May, H., Pence, A., Rayna, S., Swadener, B. B., \& Vandenbroeck, M. (2016). The Organisation for Economic Co-operation and Development's International Early Learning Study: Opening for debate and contestation. Contemporary Issues in Early Childhood, 17(3), 343-351.

OECD. (1960). Convention on the Organisation for Economic Co-operation and Development. https://www.oecd.org/general/conventionontheorganisationforeconomicco-operationanddevelopment.htm.

OECD. (2001). Starting strong: Early childhood education and care. Paris: OECD.

OECD. (2006). Starting strong II: Early childhood education and care. Paris: OECD.

OECD. (2012). Starting strong III: A quality toolbox for early childhood education and care. Paris: OECD.

OECD. (2015). Starting strong IV: Monitoring quality in early childhood education and care. Paris: OECD.

OECD. (2017). Starting strong V: Transitions from early childhood education and care to primary education. Paris: OECD.

OECD. (2018a). Early learning matters. Paris: OECD.

OECD. (2018b). Education at a glance 2018: OECD indicators. Paris: OECD.

Ochs, K., \& Phillips, D. (2004). Processes of educational borrowing in historical context. In D. Phillips \& K. Ochs (Eds.), Educational policy borrowing: Historical perspectives (s. 7-23). Oxford: Symposium Books.

Olk, T. (2010). Investing in children? Changes in policies concerning children and families in European countries. In M. Ajzenstadt \& J. Gal (Eds.), Children, gender and families in mediterranean welfare states. Children's well-being: Indicators and research, vol. 2 (s. 3-33). Dordrecht: Springer.

Paananen, M., Lipponen, L., \& Kumpulainen, K. (2015). Hybridisation or ousterisation? The case of local accountability policy in Finnish early childhood education. European Educational Research Journal, 14(5), 395-417.

Pal, L. A. (2012). Frontiers of governance: The OECD and global public management reform. Houndmills: Palgrave Macmillan.

Pence, A. (2016). Baby PISA: Dangers that can arise when foundations shift. Journal of Childhood Studies, 41(3), 54-58.

Phillips, D., \& Ochs, K. (2003). Processes of policy borrowing in education: Some analytical and explanatory devices. Comparative Education, 39(4), 451-461. 
Portnoi, L. M. (2016). Policy borrowing and reform in education: Globalized processes and local contexts. New York: Palgrave Macmillan.

Quinlivan, A., \& Schön, E. (2002). Breaking down the barriers? New public management in the European Commission. Journal of Public Affairs, 2(2), 19-32.

Rada Európskej únie. (2009). Závery Rady z 12. mája 2009 o strategickom rámci pre európsku spoluprácu vo vzdelávaní a odbornej príprave („ET 2020“) (2009/C 119/02). Brusel: Rada Európskej únie.

Rada Európskej únie. (2015). Závery Rady o úlohe vzdelávania v ranom detstve a primárneho vzdelávania pri podpore tvorivosti, inovačnosti a digitálnej kompetencie (2015/C 172/05). Brusel: Rada Európskej únie.

Schleicher, A. (2019). Helping our youngest to learn and grow: Policies for early learning. International summit on the teaching profession. Paris: OECD Publishing.

Shuey, E. A., \& Kankaraš, M. (2018). The power and promise of early learning. OECD education working paper No. 186. Paris: OECD.

Shuey, E. A., Kim, N., Cortazar, A., Poblete, X., Rivera, L., Lagos, M. J., Faverio, F., \& Engel, A. (2019). Curriculum alignment and progression between early childhood education and care and primary school: $A$ brief review and case studies. OECD education working paper No. 193. Paris: OECD.

Schreiber, N. (2009). Die Einführung der neuen Bildungspläne in Kindertageseinrichtungen Ergebnisse von Begleitstudien in drei Bundesländern. Diskurs Kindheits- und Jugendforschung, 4(3), 431-437.

Ständige Konferenz der Kultusminister der Länder in der Bundesrepublik Deutschland. (2004). Gemeinsamer Rahmen der Länder für die frühe Bildung in Kindertageseinrichtungen. Bonn/Berlin: KMK.

Taguma, M., Litjens, I., \& Makowiecki, T. (2012). Quality matters in early childhood education and care: Slovak Republic 2012. Paris: OECD.

Tolofari, S. (2005). New public management and education. Policy Futures in Education, 3(1), 75-89.

Turunen, T. A., \& Rafferty, J. (2013). Insights beyond neo-liberal educational practices: the value of discourse analysis. Educational Research for Policy and Practice, 12(1), 43-56.

Urban, M. (2018). (D)evaluation of early childhood education and care? A critique of the OECD's International Early Learning Study. In M. Matthes, L. Pulkkinen, C. Clouder, \& B. Heys (Eds.), Improving the Quality of Childhood in Europe, Volume 7 (s. 91-99). Brussels: Alliance for Childhood European Network Foundation.

Vero, J. (2012). From the Lisbon strategy to Europe 2020: The statistical landscape of the education and training objectives through the lens of the capability approach. Social Work and Society, 10(1), 1-16.

Korešpondenčná adresa: prof. PaedDr. Ondrej Kaščák, PhD.

PdF TU v Trnave Priemyselná 4 91843 Trnava Slovensko okascak@truni.sk 